\title{
STADIUM HIV/AIDS DAN TINGKAT STRES: KORELASI KEDUANYA
}

\author{
Ahmad Ikhlasul Amal ${ }^{1}$, Retno Setyawati ${ }^{2}$ \\ ${ }^{1}$ Fakultas Ilmu Keperawatan, Universitas Islam Sultan Agung \\ Email: ahmad.ikhlasul@unissula.ac.id \\ ${ }^{2}$ Fakultas Ilmu Keperawatan, Universitas Islam Sultan Agung \\ email: retno.fik@gmail.com
}

\begin{abstract}
Infectious diseases that are still of concern to many circles, namely HIV / AIDS. There is still an increase in some cases. Besides, this disease makes sufferers or people who are often known as people living with HIV / AIDS (PLWHA) experience both physical and psychological problems. The physical problems experienced by PLWHA, of course, depend on the stage of the patient's disease. PLWHA who experience physical problems may experience stress due to their illness. The purpose of this study was to find the relationship between HIV stage and stress levels. This type of research is a quantitative observational study with a correlation analytic design with a consecutive sampling technique. Data collection using a questionnaire with several respondents as many as 38 people. The data were analysed statistically using the Spearmen Rho statistical test. Based on the data, it was found that from 38 research respondents, most of them were 20-60 years old (76.3\%). Themajority of people with HIV / AIDS were male, namely 23 people (60.5\%) with most of the occupations of HIV / AIDS sufferers being private (63.2\%). Respondents' HIV was at stage II (50\%) and III (50\%). The level of stress experienced by HIV / AIDS sufferers is quite good, namely: at a level I (31.57) and II (68.43). $r=$ 174, $p$-value $=0.283$, there is no correlation between HIV stage and stress level.
\end{abstract}

Keywords : HIV/AIDS, Stadium, Stress Level

\section{PENDAHULUAN}

Penyakit infeksi yang masih menjadi perhatian banyak kalangan yaitu HIV/AIDS. Hal ini dikuatkan dengan alasan karena masih adanya peningkatan jumlah kasus. Selain itu penyakit ini membuat penderitanya atau yang sering dikenal dengan Orang dengan HIV/AIDS (ODHA) mengalami masalah baik fisik maupun psikologis. Penting bagi tenaga kesehatan untuk memberikan perawatan yang komprehensif pada penyakit kronis ini agar mencegah kondisi perburukan pasien (Ledda et al., 2017). Masalah tersebut tentunya perlu ditangani mengingat kasus kejadian penyakit ini masih mengalami peningkatan.
Kejadian HIV di Indonesia masih mengalami peningkatan. Data tahun 2006 menunjukkan 7000 kasus dan meningkat menjadi 48.000 pada 2017 (Riono \& Challacombe, 2020). Jumlah kasus HIV/AIDS di Jawa Tengah menempati urutan ke lima terbanyak se Indonesia. Kasus terbanyak kedua di provinsi Jawa Tengah ditemukan di Kota Semarang. Peningkatan tersebut ditemukan pada beberapa kelompok rentan diantaranya penyukas sesama jenis, pekerja seks komersial dan beberapa lainnya ditemukan pada ibu rumah tangga (Noffritasari, 2020). 
Peningkatan yang terjadi pada kasus HIV/AIDS, secara umum akan membuat stigma yang saat ini masih melekat dimasyarakat menjadi hal yang semakin penting untuk ditangani. Penderita HIV/AIDS dimungkinkan akan mengalami diskriminasi, stigma, dari keluarga maupun masyarakat. (Wahyuni, 2018) mengutarakan bahwa stigma yang dialami justru akan memperlambat perubahan perilaku penderita HIV-AIDS untuk menjadi lebih baik dalam menjalani hidup. Alangkah baiknya apabila keluarga dan masyarakat memberikan dukungan dan motivasi kepada penderita HIV-AIDS. Hal tersebut dimaksud agar penderita tidak mengalami masalah fisik dan psikologis yang berkepanjangan.

Gangguan fisik yang dialami oleh ODHA tentunya tergantung dari stadium penyakit penderita tersebut. Stadium HIV dibagi kedalam empat kategori. Keempat kategori tersebut didapatkan atas dasar kumulatif dari Cluster of Differentiation 4 (CD4). Ini menjadi salah satu hal utama dalam peran dan fungsi kekebalan dari sel darah putihuntuk melawan patogen yang menyebabkan munculnya tanda gejala atau gangguan fisik pada ODHA. Hal ini juga akan mempengaruhi peningkatan resiko terjangkitnya infeksi oportunistik (Asis et al., 2018).

Respon psikologis (penerimaan diri) pada ODHA biasanya muncul akibat stigma karena ketidaktahuan masyarakat atau keluarga tentang penyakit tersebut. ODHA dapat menunjukkan perilaku pengingkaran, apabila pengingkaran tidak dapat dipertahankan maka akan berubah menjadi marah dan memarahi segala sesuatu yang ada disekitarnya. (Cahyono \& Sony, 2017). Hal tersebut dapat dikategorikan dalam kondisi psikologis yang tidak stabil atau depresi sehingga akan berisko menimbulkan stress. Stres yang muncul pada ODHA akan berdampak pada masalah yang berhubungan dengan kesehatan, psikologi dan interaksi interpersonal.

Penelitian terkait tentang respons penderita HIV/AIDS pernah dilakukan Juwita (2008), penelitian tersebut berjudul sindrom depresif pada penderita HIV/AIDS di RSUP Haji Adam Malik Medan. Meneliti berjumlah 100 orang datang ke poliklinik posyansus dan menjalani rawat inap di RSUP Adam Malik Medan penelitian dilakukan dari bulan Juli sampai Oktober 2008. Sindrom depresif paling banyak terjadi pada penderita HIV/AIDS (34\%), diikuti sindrom depersif ringan (28\%), tidak depresif (26\%), depresif berat (12\%). Namun belum ada yang meneliti tentang hubungan antara stadium HIV/AIDS pada tingkatan stress, hal ini menjadi keterbaruan dibandingkan dengan penelitian yang telah ada sebelumnya.

Berdasarkan uraian latarbelakang tersebut, penulis ingin menyampaikan bahwa tujuan dari penelitian ini adalah untuk mengetahui apakah terdapat hubungan antara stadium HIV dengan tingkat stress penderita HIV/AIDS.

\section{METODE PENELITIAN}

Penelitian kuantitatif ini menggunakan desain analitik korelasi dengan pendekatan cross sectional. Tempat pengambilan data penelitian dilakukan di Balai Kesehatan Masyarakat Wilayah Semarang.

Populasi terjangkau pada penelitian ini adalah 94 pasien HIV. Sampel pada penelitian ini adalah sejumlah 38responden yang sebelumnya telah ditentukan berdasarkan kriteria inklusi dan eksklusi, dengan teknik consecutive sampling. Instrumen penelitian yang 
digunakan yaitu rekam medis untuk menunjukkan stadium HIV-AIDS serta kuesioner The Depression Anxiety Stress Scale 42 (DASS).

Analisis data yang digunakan dalam penelitian ini meliputi uji univariat dan bivariat. Uji univariat menggunakan distribusi frekuensi, sedangkan uji bivariate untuk mengetahui korelasi kedua variabel digunakan uji spearman rho.

\section{HASIL}

Tabel 1. Distribusi Frekuensi Partisipan Berdasarkan Karakteristik di Balai Kesehatan Masyarakat Wilayah Semarang

\begin{tabular}{cccc}
\hline No & Usia & $\mathbf{n}$ & $\mathbf{\%}$ \\
\hline 1 & $11-19$ & 9 & 23,7 \\
2 & $20-60$ & 29 & 76,3 \\
\hline & Total & $\mathbf{3 8}$ & $\mathbf{1 0 0}$ \\
\hline No & Jenis Kelamin & $\mathbf{n}$ & $\mathbf{\%}$ \\
\hline 1 & Perempuan & 15 & 39,5 \\
2 & Laki-laki & 23 & 60,5 \\
\hline \multicolumn{2}{c}{ Total } & $\mathbf{3 8}$ & $\mathbf{1 0 0}$ \\
\hline No & Pendidikan & $\mathbf{n}$ & $\mathbf{\%}$ \\
& Terakhir & & \\
\hline 1 & SD & 9 & 23,7 \\
2 & SMP & 9 & 23,7 \\
3 & SMA & 20 & 52,6 \\
\hline & Total & $\mathbf{3 8}$ & $\mathbf{1 0 0}$
\end{tabular}

Berdasarakan tabel 1 memperlihatkan bahwa mayoritas partisipan termasukdalam kategori usia dewasa. Sedangkan untuk variabel jenis kelamin ditemukan mayoritas laki-laki. Adapun untuk variabelpendidikan terakhir didapatkan mayoritas partisipan adalah lulusan SMA.
Tabel 2. Distribusi Frekuensi Partisipan Berdasarkan Stadium HIV/AIDS

\begin{tabular}{ccc}
\hline Stadium HIV/AIDS & $\mathbf{n}$ & $\mathbf{\%}$ \\
\hline Stadium I & 0 & 0 \\
Stadium II & 19 & 50 \\
Stadium III & 19 & 50 \\
Stadium IV & 0 & 0 \\
\hline Total & $\mathbf{3 8}$ & $\mathbf{1 0 0}$
\end{tabular}

Berdasarkan tabel 2 didapatkan bahwa stadium II dan III ditemukan dalam jumlah yang sama dalam keseluruhan partisipan.

Tabel 3. Distribusi Frekuensi Partisipan Berdasarkan Tingkat Stress HIV/AIDS

\begin{tabular}{ccc}
\hline Tingkat Stress & $\mathbf{n}$ & $\mathbf{\%}$ \\
\hline Normal & 12 & 31,57 \\
Ringan & 27 & 68,43 \\
Sedang & 0 & 0 \\
Berat & 0 & 0 \\
Sangat Berat & 0 & 0 \\
\hline Total & $\mathbf{3 8}$ & $\mathbf{1 0 0}$
\end{tabular}

Berdasarkan tabel 3 didapatkan bahwa tingkatan stress ditemukan mayoritas kategori mengalami tingkat stress ringan.

Tabel 4. Hubungan Stadium HIV/AIDS dengan Tingkatan Stress Pada Responden di Balai Kesehatan Masyarakat Wilayah Semarang

\begin{tabular}{ccccc}
\hline Variabel & \multicolumn{2}{c}{ Tingkat Stress } & r & p \\
\hline Stadium & Normal & Ringan & & \\
\cline { 1 - 4 } $\begin{array}{c}\text { Stadium } \\
\text { II }\end{array}$ & 4 & 15 & -174 & 0,283 \\
\cline { 1 - 1 } $\begin{array}{c}\text { Stadium } \\
\text { III }\end{array}$ & 7 & 12 & & \\
\cline { 1 - 1 } Total & $\mathbf{3 8}$ & & &
\end{tabular}

Berdasarkan tabel 4 ditemukan nilai $\mathrm{p}$ value $(0,283)$ yang bermakna bahwa tidak terdapat hubungan antara stadium dengan tingkat stress pasien HIV/AIDS 


\section{PEMBAHASAN}

\section{a. Usia}

Tabel 1 menunjukan dominasi usia respoonden pada kategori dewasa sedangkan minoritas pada usia remaja. Hasil tersebut selaras dengan penelitan (Ilham, Triliana, \& Tilaqza, 2020) yang menunjukkan bahwa kelompok dewasa rentan untuk mengalami infeksi HIV. Hal tersbut dikarenakan peningkatan usia akan membuat perubahan fungsi dalam daya tahan tubuh. Cell Mediated Immunity (CMI) akan menurun pada penambahan usia. Penderita HIV yang berada pada usia dewasa hingga bertambahnya dewasa juga akan beresiko menderita infeksi oportunistik, ditambahpula dengan maslaah imunodefisiensi dari penyakit HIV. Hal tersbut dapat dicegah dengan melakukan upaya perbaikan hidup dan tentunya menjaga stabilitas respon psikologis.

\section{b. Jenis Kelamin}

Data yang ditemukan menunjukkan dominasi laki-laki pada penelitian ini. (Manalu, Harahap, \& Sinurat, 2019) menemukan data yang selaras, bahwa lakilaki lebih dominan dalam kasus HIV/AIDS. Data penderita laki-laki diduga lebih banyak diasumsikan karena beberapa alas an. Alasan tersebut diataranya meningkatnya kasus HIV pada kelompok lelaki suka lelaki, pengguna jasa seks komersial yang didominasi laki-laki dan beberapa penyebab lainnya adalah obat terlarang atau pengguna jarum suntik.

\section{c. Pendidikan Terakhir}

Hasil penelitian yang menunjukkan mayotitas reponden adalah lulusan sekolah menengah atas (SMA). Hal ini serupa dengan penelitian dari (Surya Antara, 2019) yang juga mendapatkan data terbanyak pasien HIV dalam penelitiannya di klinik Voluntary Counselling Testing (VCT) RSUP Sanglah adalah lulusan SMA.

\section{d. Stadium HIV/AIDS}

Data temuan studi menunjukkan besaran jumlah yang sama antara stadium II \& III. Hal ini dikarenakan respondenyang diambil datanya adalah pasien yang datang pada acara kelompok dukungan sebaya dan bersedia menjadi responden.

Empat stadium klinis HIV/AIDS pada dasarnya akan menunjukkan penurunan jumalh CD4, yang berarti bahwa jumlah virus atau viral load dalam tubuh penderita tersebut mengalami peningkatan. Pasien yang mengalami penurunaan CD4 akan mudah mengalami infeksi sekunder ditambah pula jika pasien tersebut telah berstatus AIDS (CD4 kurang dari 200 $\mathrm{sel} / \mathrm{mm} 3$ ) maka dapat meningkatkan risiko kematian. Penderita HIV/AIDS dengan CD4 $100 \mathrm{sel} / \mathrm{mm} 3$ atau kurang ketika mereka mulai ARV, secara bermakna meningkatkan resiko mortalitas. Penderita HIV/AIDS yang memulai terapi ketika jumlah CD4 antara 200-350 lebih dapat mnurunkan resiko mortalitas (Asis et al., 2018).

Meskipun penderita HIV/AIDS dengan stadium lanjut dan memiliki jumlah CD4 diatas 350 dapat bertahan hidup, namun belum tentu selaras dengan kuaitas hidupnya. Menurut (Wiyati, 2019) lama terdiagnosis HIV/AIDS belum dapat mempengaruhi kualitas hidup ODHA jika faktor eksternal lainnya tidak diperbaiki. Faktor tersebut diantaranya dukungan sosial dan msalah psikologis lainnya.

\section{e. Tingkat stress}

Temuan data studi ini dengan menggunakan kuesioner DASS didapatkan responden mayoritas berada pada stress ringan. Peneliti berasumsi bahwa responden yang diambil datanya saat pertemuan kelompok dukungan sebaya telah saling berbagi informasi dan pengalaman sehingga telah beradaptasi dengan cukup baik terhadap stress sebagai seorang ODHA. 
Penderita HIV/AIDS di stadium II dan III memiliki tingkat stress rendah, mereka tidak fokus pada kematian maupun masa depannya lagi. Mereka dapat lebih baik dalam menghadapi penyakitnya, diskriminasi dan stigma yang diterima di masyarakat. Penerimaan diri seluruh penderita mengalami perbaikan yang efektif, sehingga seluruh KDS menerima diri apa adanya sebagai pengidap HIV/AIDS.

Roy dalam teorinya mengenai adaptasi menyatakan bahwa adaptasi dari sel imun yang mempunyai hormon kortisol dapat tercipta apabila dalam waktu lain menderita stres atau yang biasa dikenal dengan mekanisme regulator. Faktor pemahaman tentang cara penularan HIV \& AIDS oleh individu turut memengaruhi tingkat stress yang dialami pasien. Respons adaptasi psikologis terhadap stresor menurut Kubler Ross (1974) dalamPotter \& Perry (2005) menguraikan lima tahap reaksi emosi seseorang terhadap stresor yakni 1) pengingkaran; 2) marah;

3) tawar menawar; 4) depresi; dan 5) menerima (Nursalam, Ninuk, Bakar, Purwaningsih, \& Candra, 2014).

SelaIn telah beradaptasi dengan stress tentunya mekanisme koping juga berperan dalam penangan stress pasien HIV/AIDS. Hal ini seperti disampaikan oleh (Mukherjee, Lahiry, Mukherjee, Choudhury, \& Sinha, 2017) yang menyampaikan mengingat situasi stress yang dialami oleh ODHA, dalam banyak hal ODHA harus mengadopsi strategi pertahanan untuk mengatasi stres yang melekat terkait dengan stigmatisasi. Freud dalam teori psikoanalitiknya mendefinisikan mekanisme pertahanan sebagai strategi psikologis bawah sadar yang dimainkan oleh berbagai entitas untuk menghadapi kenyataan dan untuk mempertahankan citra diri.

\section{f. Hubungan Antara Stadium dengan Tingkat Stress pada HIV/AIDS}

Tabel 4 menunjukkan tidak adanya hubungan antara stadium HIV dengan tingkat stress. Ini berarti bahw Peneliti berasumsi bahwa responden yang diambil datanya telah melewati lima fase reaksi emosi sampai tahap acceptance paska terdiagnosis HIV/AIDS. Hal tersebut ditunjang dengan kehadiran para responden yang rutin mengikuti kegiatan kelompok dukungan sebaya antar sesama ODHA. Dalam kelompok tersebut diyakini menjadi salah satu koping adaptif dari ODHA untuk menghadapi masalah psikososial seperti stigma masyarakat atau keluarga.

Faktor psikososial mungkin memainkan peran penting dalam perkembangan infeksi HIV. Morbiditas psikologis dan koping disfungsional merupakan bagian dari psikososial pengaruh yang berkaitan dengan perkembangan penyakit atau stadium HIV (Ezeh \& Ezeh, 2019)

Asumsi peneliti mengenai stadium HIV yang tidak berkorelasi dengan tingkat stress selaras dengan pendapat (Utomo, 2008) ada tahapan stress yang disebut optimum stress, yaitu seseorangmengalami kehidupan membaik akibat proses manajemen yang baik oleh dirinya. Selain itu penelitian oleh (Wulandari, Lestari \& Herani, 2013) disampaikan bahwa pasien penyakit kronis yang memiliki persepsi positif terhapad penyakitnya cenderung memiliki tingkat stress yang rendah. Proses adaptasi terhadap penyakit menjadi penting untuk dilakukan oleh pasien. 


\section{KESIMPULAN}

Hasil penelitian menyimpulkan bahwa tidak terdapat korelasi antara stadium HIV/AIDS dengan tingkat stress penderita HIV/AIDS. Peneliti menyarankan untuk dilakukan penelitian dengan jumlah sampel yang lebih besar. Selain itu penelitian perihal faktor yang mempengaruhi stress pada pasien HIV/AIDS juga perlu dilakukan.

\section{REFERENSI}

Asis, N. P., Tilaqza, A., Airlangga, H., Asis, N. P., Tilaqza, A., \& Airlangga, H. (2018). Pengaruh Stadium HIV terhadap Infeksi Oportunistik , Penggunaan Antiretroviral dan Antibiotik pada Pasien HIV di Rumah Sakit X Kota Malang The Effect ofHIV Stadium on Opportunistic Infection , Antiretroviral and Antibiotic Use in HIV Patients at X Hospit. (0341), 818.

Cahyono, W., \& Sony, P. I. (2017). Gambaran Pengaruh Stigma Negatif Pada Penderita HIV Positif Di Nganjuk. Jurnal Ilmu Keperawatan Dan Kebidanan., 8(2), 72-78.

Ezeh, O. H., \& Ezeh, C. C. (2019). Correlates and Predictors of Psychological Morbidity in HIVInfected Persons: A Cross Sectional Study. Open Journal of Medical Psychology, 08(04), 57-65. https://doi.org/10.4236/ojmp.2019.84 006

Ilham, M., Triliana, R., \& Tilaqza, A. (2020). the Role of Age, Gender , Job , and Health Financing To Hospitalization and Secondary Infection in Hiv Patients in Malang Hospital. Jurnal Bio Komplementer Medicine, 7(1), 1-9.

Ledda, C., Cicciù, F., Puglisi, B., Ramaci, T., Nunnari, G., \& Rapisarda, V. (2017). Attitude of health care workers (HCWs) toward patients affected by HIV/AIDS and drug users: A cross-sectional study. International Journal of Environmental Research and Public Health, 14(3). https://doi.org/10.3390/ijerph1403028 4

Manalu, R. M., Harahap, S. Y., \& Sinurat, I. (2019). Faktor-Faktor Yang Mempengaruhi Kejadian Infeksi Hiv Pada Usia Produktif Di Komite Aids Hkbp Balige. Indonesian Trust Health Journal, 2(2), 190-198. https://doi.org/10.37104/ithj.v2i2.35

Mukherjee, A., Lahiry, S., Mukherjee, A., Choudhury, S., \& Sinha, R. (2017). Study on Defense Mechanisms to Cope With Stress Due to Stigma Among People Living With HIV/AIDS Reported in Eastern India: A Single Center Experience. Integrative Medicine Insights, 8. https://doi.org/10.1177/11799161177 42919

Noffritasari, B. (2020). Human Immunodeficiency Virus (Hiv) Prevention Program Among Men Who Have Sex With Men (Msm) in Semarang City. Jurnal Administrasi Kesehatan Indonesia, 8(1), 91. https://doi.org/10.20473/jaki.v8i1.202 0.91-106

Nursalam, Ninuk, Bakar, A., Purwaningsih, \& Candra. (2014). Respons Bio-Psiko-Sosio-Spiritual Pada Keluarga Tenaga KerjaIndonesia Yang Terinfeksi Hiv. Jurnal Ners, 9(2), 209-216.

Riono, P., \& Challacombe, S. J. (2020). HIV in Indonesia and in neighbouring countries and its social impact. Oral Diseases, 26(S1), 28-33. https://doi.org/10.1111/odi.13560

Surya Antara, I. N. B. (2019). Profil Gangguan Fungsi Kognitif Pasien 
HIV/AIDS di Klinik VCT RSUP

Sanglah. Medicina, 50(1), 104-108.

https://doi.org/10.15562/medicina.v5

$0 \mathrm{i} 1.289$

Utomo, U. (2008). Hubungan Antara Model-Model Coping Stres (Universitas Islam Negeri Maulana Malik Ibrahim). Retrieved from http://etheses.uinmalang.ac.id/4372/1/04410005.pdf

Wahyuni, A. (2018). Faktor-Faktor Yang Mempengaruhi Perubahan Perilaku Pasien Hiv/Aids. Human Care Journal, $\quad l(2), \quad 1-10$. https://doi.org/10.32883/hcj.v1i2.5
Wiyati, T. G. K. (2019). Hubungan Antara Lama Terdiagnosa Dengan Kualitas Hidup Orang Dengan Hiv / Aids Di Yayasan Victory Plus Tahun 2019 Hubungan Antara Lama Terdiagnosa Dengan Kualitas Hidup OrangDengan Hiv / Aids Di Yayasan Victory Plus Tahun 2019. Skripsi. 